\title{
DEPRECIABILITY OF GOING CONCERN VALUE
}

The accounting concept of "going concern value" had for some two decades lurked quietly in an unilluminated corner of the tax law, from which it has engendered theoretical confusion for tax scholars, practitioners and courts. No consistent, clear understanding of the meaning of "going concern value" has been developed; as a result, there is an unsettling lack of unanimity as to its proper tax treatment. In particular, courts have divided over the legitimacy of depreciating or amortizing that portion of the value of a business which is appropriately allocated to such an account, and in the process have failed to justify either position. ${ }^{1}$

\section{Goodwill and Going Concern Value Distinguished}

Goodwill is the going concern value of a business in excess of the liquidating value of its plant, equipment, receivables, and other balance sheet assets. ${ }^{2}$

$$
\text { * } \quad * \quad *
$$

The going value ... is not to be confused with good will, in the sense of that "element of value which inheres in the fixed and favorable consideration of customers, arising from an established and well-known and wellconducted business . . . ."3

Any analysis of going concern value must at the very outset seek to dispel the considerable confusion sometimes brought about by its name. Since the term itself is subtly reminiscent of "goodwill," it is not altogether surprising that scholars have on occasion used the terms interchangeably. ${ }^{4}$ Even the courts, while repeatedly insisting that the two terms represent entirely discrete concepts, have frequently failed to offer a reasoned explication of the perceived difference. ${ }^{5}$

${ }^{1}$ See Northern Natural Gas Co. v. United States, 470 F.2d 1107 (8th Cir.), cert. denied, 93 S. Ct. 2773 (1973); United States v. Cornish, 348 F.2d 175 (9th Cir. 1965); TexasEmpire Pipe Line Co., 10 T.C. 140 (1948), aff d, 176 F.2d 523 (10th Cir. 1949).

2 E. Colson, Federal Taxation of Sales, Exchanges and OTHER Transfers 122 (1971) (emphasis added).

${ }^{3}$ Los Angeles Gas \& Elec. Corp. v. Railroad Comm'n, 289 U.S. 287, 313 (1933) (emphasis added).

${ }^{4}$ See Note, Amortization of Intangibles: An Examination of the Tax Treatment of Purchased Goodwill, 81 HARv. L. REv. 859, 865-67 (1968) [hereinafter cited as Amortization of Intangibles] ("going business" value used to describe a component of goodwill).

${ }^{5}$ See, e.g., Northern Natural Gas Co. v. United States, 470 F.2d 1107, 1108 (8th Cir.), cert. denied, 93 S. Ct. 2773 (1973); United States v. Cornish, 348 F.2d 175, 184 (9th Cir. 1965). 


\section{A. Goodwill}

Goodwill has traditionally been described qualitatively ${ }^{6}$ as the preference of customers which arises from such sources as excellence of reputation, efficiency of service and skill in utilization of trademarks, brand names and other forms of advertising. ${ }^{7}$ Other goodwill elements, less often recognized, include creditor preference and the high productivity which flows from capable and contented management and labor forces. ${ }^{8}$ Quantitatively, goodwill has been measured by capitalization of business earnings in excess of a normal industry-wide rate of return. ${ }^{9}$

A definition of goodwill using only this quantitative measure would, however, be over-expansive and economically misleading, since factors not properly classified as goodwill may contribute to the "excess" investment return. ${ }^{10}$ Accordingly, neither the courts nor the Internal Revenue Service have treated goodwill as so all-inclusive; intangible assets with reasonably determinable useful lives, for example, are depreciable ${ }^{11}$ and clearly not included within goodwill. ${ }^{2}$

Although the Internal Revenue Service prefers a separate appraisal of goodwill value, ${ }^{13}$ in practice goodwill has often been simply measured as a residual intangible asset, that element of value which remains after the fair market values of tangible and

${ }^{6}$ Note, An Inquiry into the Nature of Goodwill, 53 Colum. L. Rev. 660, 662-63 (1953) [hereinafter cited as Nature of Goodwill].

${ }^{7}$ See Los Angeles Gas \& Elec. Corp. v. Railroad Comm'n, 289 U.S. 287, 313 (1933);

White Tower System v. White Castle System, 90 F.2d 67, 69 (6th Cir.), cert. denied, 302 U.S. 720 (1937); Amortization of Intangibles, supra note 4, at 861-63) Nature of Goodwill, supra note 6 , at $664-65$.

A similar description of goodwill may be found in Haberle Crystal Springs Brewing Co. v. Clarke, 30 F.2d 219 (2d Cir. 1929), rev'd on other grounds, 280 U.S. 384 (1930):

A going business has a value over and above the aggregate value of the tangible property employed in it. Such excess of value is nothing more than the recognition that, used in an established business that has. won the favor of its customers, the tangibles may be expected to earn in the future as they have in the past. The owner's privilege of so using them, and his privilege of continuing to deal with customers attracted by the established business, are property of value. This latter privilege is known as goodwill.

30 F.2d at 221.

${ }^{8}$ Amortization of Intangibles, supra note 4 , at $862,863$.

${ }^{9}$ See, e.g., Philadelphia Steel \& Iron Corp., 33 P-H Tax Ct. Mem. 614, 623 (1964), aff'd per curiam, 344 F.2d 964 (3d Cir. 1965); Amortization of Intangibles, supra note 4, at 860. Cf. Nature of Goodwill, supra note 6, at 661, 662; see also Rev. Rul. 59-60, 1959-1 Cum. BuLl. 237; Rev. Rul. 54-77, 1954-1 Cum. BuLl. 187; Rettig, Tax Recovery of the Cost of Intangible Assets: Careful Analysis and Planning Necessary, 18 J. TAXation 154 (1963).

IU See Ruhe, The IRS Position on Allocation of Intangibles in Business Acquisitions, $120 \mathrm{~J}$. Account., Sept., 1965, at 50, 52, 53.

11 Treas. Reg. \$ 1.167(a)-3 (1956). See, e.g., Northern Natural Gas Co. v. O'Malley, 277 F.2d 128 (8th Cir. 1960), acq., Rev. Rul. 71-120, 1971-1 Cum. Bull. 79 (easement); Ida Ambrose, 15 CCH Tax Ct. Mem. 643 (1956) (contract); Treas. Reg. $\$ 1.167$ (a)-6 (1956) (patents and copyrights). See also Schenk, Depreciation of Intangible Assets: The Uncertainty of Death and Taxes, 13 WAYNE L. REv. 501, 502 (1967).

${ }_{12}$ See, e.g., Dodge Bros., Inc. v. United States, 118 F.2d 95, 99 (4th Cir. 1941); X-Pando Corp., 7 T.C. 48, 53 (1946).

${ }^{13}$ See Rev. Rul. 68-609, 1968-2 Cum. Bull. 327. 
identified intangible assets have been subtracted from the total worth of a business. ${ }^{14}$

Evidently, such a practice will lead to an asset valuation which wholly ignores "going concern value," unless that value is specifically and separately recognized. If there is any rationale on which going concern value can be distinguished from goodwill for depreciation purposes, then it is important to develop a method of separating the two concepts for tax accounting purposes.

\section{B. Going Concern Value}

"Going concern value" first confronted the federal judiciary in utility regulation cases. Attempting to determine the appropriate asset base on which utility rates were to be calculated, the Supreme Court recognized that the customer preference or excess earnings of a utility-though normally indicia of goodwill ${ }^{15}$-arise primarily from a utility's monoply power, rather than from its good reputation or good service. Thus, while acknowledging that the assets comprising a particular utility were worth more than the strict sum of the fair market values of each asset if sold separately, the Court held that such excess could not properly be considered goodwill, and denominated that excess - which it included in the asset base- "going concern value." ${ }^{16}$ This analysis at least recognizes the existence of going concern value, but it does not provide a definition of the term more certain than "that portion of excess investment return not constituting goodwill." While monopoly power was considered to be the source of going concern value in the utility cases, such value has been recognized in other industries, arising from other sources and requiring different depreciation treatment.

Going concern value, as the term is most frequently used, may be defined as a composite of several unaccounted-for or prematurely-expensed business development expenditures ${ }^{17}$ which contribute to future earnings. This abstract definition may best be clarified by directing attention to a hypothetical entre-

"4 See, e.g., George J. Staab, 20 T.C. 834, 840 (1953).

${ }^{15}$ See Amortization of Intangibles, supra note 4, at 860; Nature of Goodwill, supra note 6.

${ }^{16}$ For cases following a similar approach, see Los Angeles Gas \& Elec. Corp. v. Railroad Comm'n, 289 U.S. 287, 313 (1933); McCardle v. Indianapolis Water Co., 272 U.S. 400, 413 (1926); Denver v. Denver Union Water Co., 246 U.S. 178, 191 (1918); Des Moines Gas Co. v. Des Moines, 238 U.S. 153, 164 (1915).

${ }_{17}$ The term "development expenditure" should not be confused with research and development expenditures, which may be at most a part of going concern value. The term "start up" expenditures would be even more misleading, however, since the outlays referred to are not necessarily limited to a start up period. And "organizational expenditure," properly used, would refer only to corporate organization. "Development expenditures," therefore, is used to refer to all the various elements of going concern value while the term "research and experimental expenditure," following the lead of $\S 174$ of the code, will be used to refer to specific research and development costs. 
preneur whose investment return exceeds the industry-wide norm. Although this excess return will be attributable to goodwill if generated by any of the traditional goodwill components, ${ }^{18}$ it would in many cases be wholly erroneous to view it as reflecting an abnormally high rate of return. Instead, it may be generated by expenditures made during an earlier accounting period which, despite their continuing effect on earnings, were deducted as current expenses; or by efforts and expenditures which have never been accounted for. Such expenditures include sums required for initial research and development, for the organization of buildings and equipment into a harmoniously operating plant, for the molding of employees into competent management and labor forces, and for the establishment of beneficial consumer and creditor contacts. ${ }^{19}$

Entrepreneurs, moreover, frequently substitute considerable outlays of their own labor for the labor of salaried organizers, although the value of their efforts may go wholly unrecorded on corporate balance sheets. Because of these mismatched ${ }^{20}$ or unrecorded "hidden assets," an entrepreneur will reap added revenue in the future. Had such items been added to the balance sheet during the accounting periods in which they began to generate revenue, the earnings for the periods they affect would have fallen closer to the normal rate of return on the total "assets." Instead, because these "assets" went unrecorded, the actually-recorded physical assets of the business appear to generate an unusually high rate of return. ${ }^{21}$

\section{The Depreciation Problem}

The question whether going concern value is depreciable is most likely to arise in the case of the purchase of an operating business. ${ }^{22}$ This is because present tax accounting tends to favor the person involved in starting up an enterprise: going concern expenditures which are treated as current expenses can be used to offset current income in full, while unaccounted-for entre-

\footnotetext{
${ }^{18}$ See Heath, Property Valuation Problems and the Accountant, $117 \mathrm{~J}$. Account., Jan., 1964, at 54; text accompanying notes 6-12 supra.

${ }^{19}$ Such costs as these are expensed currently or written off over a brief time span although generating revenues over succeeding accounting periods. See T. FIFLIs \& H. KRIPKE, ACCOUNTING For BUSINESS LAWYERS 176, 177 (1971) [hereinafter cited as FIFLIS \& KRIPKE].

${ }_{20}$ Although, in theory, to achieve proper matching there should be an accrual of future income to the period of the entrepreneur's effort, such accrual is clearly unworkable in practice, and accordingly income is recognized only in the later periods. Any amortization of the entrepreneurial effort is, moreover, impossible, as work done to earn income cannot under tax law be treated as a cost of earning income. $C f$. id.

${ }^{21}$ See generally Heath, supra note 18.

22 But see Richmond Television Corp. v. United States, 354 F.2d 410 (4th Cir. 1965) (expenditures for an employee training program-one element of going concern value-not allowed as an ordinary business expense but instead required to be capitalized and then treated as a nondepreciable intangible because of failure by the taxpayer to demonstrate that the training expenditures had a limited useful life).
} 
preneurial time and effort in effect represent income deferred to later periods. The purchaser who must treat acquired going concern value as capital is disadvantaged by contrast.

Consider the plight of a purchaser of a hypothetical Trucking Enterprise, part of whose cost for the business reflects the value of having maintenance shops suitably equipped and sized for his particular fleet of trucks. In valuing the shops and equipment therein, this factor of peculiar suitability will surely be reflected. And this suitability-one element of the going concern value of the enterprise ${ }^{23}$ - may well diminish as trucks are replaced and equipment becomes obsolete. New efforts and expenditures will thus be necessary to decide upon and provide suitable replacement equipment. Since the purchaser may be able to calculate with reasonable justification a going concern value attributable to the suitability factor, either through expert advice on organizing maintenance shops or through expert appraisals, such value would seem fully eligible for treatment as a depreciable intangible asset. Section $167^{24}$ allows a deduction from income for the exhaustion, wear and tear and obsolescence of all property used in business or for the production of income, and the regulations deny that deduction only where a reasonably estimable and limited useful life cannot be calculated. ${ }^{25}$ The weight of authority, however, supports denial of the deduction.

In the three leading cases addressing the depreciability of acquired going concern value, the taxpayers ${ }^{26}$ or lower courts ${ }^{27}$ followed a lead provided by the rate regulation cases, which had spoken of going concern value as an enhancement in the value of physical assets owing to their presence in a going business. ${ }^{28}$ They took the position that the "fair market value" of the purchased physical assets included not only the strict reproduction cost of similar assets, but also the full compensation for going concern value necessarily paid to the sellers. If accepted, this concept of fair market value would have permitted depreciation of going concern value over the life of the physical asset to which it was attached.

In Texas-Empire Pipe Line Co., the first case, ${ }^{29}$ the Tax

${ }^{23}$ Even the most expansive definition of goodwill, discussed at text accompanying note 9 supra, would not include the value of this organizational element unless it contributed to a rate of return above the industry norm. It is unrelated to the traditional "customer preference" aspect of goodwill.

${ }^{24}$ INT. Rev. CODE OF 1954, \& 167.

25 Treas. Reg. \& 1.167 (a) -3 (1956).

${ }^{26}$ Northern Natural Gas Co. v. United States, 470 F.2d 1107 (8th Cir.), cert. denied, 93 S. Ct. 2773 (1973).

${ }_{27}$ Cornish v. United States, 221 F. Supp. 658 (D. Ore. 1963), rev'd, 348 F.2d 175 (9th Cir. 1965); Texas-Empire Pipe Line Co., 10 T.C. 140 (1948), affd, 176 F.2d 523 (10th Cir. 1949).

${ }^{28}$ Compare Los Angeles Gas \& Elec. Corp. v. Railroad Comm'n, 289 U.S. 287, 313 (1933), with Northern Natural Gas Co. v. United States, 470 F.2d 1107, 1109-10 (8th Cir.), cert. denied, $93 \mathrm{~S}$. Ct. 2773 (1973).

${ }_{29} 10$ T.C. 140 (1948), aff'd, 176 F.2d 523 (10th Cir. 1949). 
Court allowed going concern value to be so apportioned among the physical assets of the business. Its decision, however, was based primarily on res judicata principles, not on the merits of apportionment. Earlier, in related litigation over Texas-Empire's tax liability for a preceding taxable year, the Board of Tax Appeals had accepted a value for the physical assets calculated by discounting to present value a projected average earnings stream of the business. ${ }^{30}$

On appeal, the Tenth Circuit required that other evidence of asset values be considered in making such a calculation, but never suggested that the Board's attitude toward going concern value was improper. ${ }^{31}$ The Board complied without elaborating on its methods, ${ }^{32}$ and the Commissioner failed to object to the Board's resultant decision on remand. ${ }^{33}$ In Texas-Empire, this failure to object was deemed to have created an estoppel which precluded objection to similar valuations for subsequent years then before the court.

In the two subsequent cases in which the depreciability of going concern value was more squarely in issue, the Eighth and Ninth Circuits have found it improper for going concern value to be included in the value of physical assets for depreciation purposes. In Cormish v. United States, ${ }^{34}$ the district court had allowed inclusion of going concern value in resolving-for purposes of depreciation-what a willing seller and willing buyer would agree was a fair price for the assets, but offered no method for calculating such a value. ${ }^{35}$ On appeal the Ninth Circuit flatly declared:

The going concern element of an operating business cannot be classified as an enhancement in market value of depreciable assets for purposes of depreciation. While the individual tangible assets may wear out and be replaced, going concern value does not wear out with the individual assets. And when a worn out tangible asset must be replaced the cost to the business of doing so is not augmented by the fact that the acquisition is to become a part of a going concern. ${ }^{36}$

The district court was directed to disregard going value as an enhancement in the value of particular physical assets, and

${ }^{30}$ Texas-Empire Pipe Line Co., 42 B.T.A. 368 (1940), rev'd, 127 F.2d 220 (10th Cir. 1942). That value, it should be noted, was based on a projection of the average earnings of the plaintiff pipeline company, not on the average earnings of similar businesses, and thus would have improperly included a goodwill value if the plaintiff's earnings exceeded industry norms.

${ }^{31} 127$ F.2d at 226.

32 Texas-Empire Pipe Line Co., 11 P-H Tax Ct. Mem. 1344 (1942).

${ }^{33} 176$ F.2d at 523 .

34221 F. Supp. 658 (D. Ore. 1963), rev'd, 348 F.2d 175 (9th Cir. 1965).

${ }^{35} I d$. at 664,665 .

${ }^{36} 348$ F.2d at 185 . 
instead to calculate a separate going concern value, which it characterized as a nondepreciable intangible. ${ }^{37}$

Similarly, Northern Natural Gas Co. v. United States, ${ }^{38}$ failing to advance significantly the reasoning curtly set forth in Cornish, held going concern value to be a separate, nondepreciable intangible. The Northern Natural Gas court also flatly declared that going concern value was not properly included in a valuation of physical assets, since it was not subject to wear and tear. Hence, the court concluded, going concern value was ineligible for the depreciation allowance contemplated by section 167, an allowance intended merely to "provide a nontaxable fund to restore income-producing assets" when their capacity to generate income ceased, or to allow a taxpayer to recoup his investment in wasting assets free of income tax. ${ }^{39}$

\section{Valuation Techniques: The Backdoor to Depreciability}

The regulations under section 167 , in allowing a depreciation deduction for exhaustion of intangible assets when a limited useful life can be estimated for such assets with reasonable accuracy, ${ }^{40}$ also require an apportionment of purchase price whenever depreciable assets are purchased along with nondepreciable assets. ${ }^{41}$ Since in the normal purchase of an operating business there will arise a question of the existence of and extent of the nondepreciable asset goodwill, ${ }^{42}$ such an apportionment will usually be necessary.

Under Regulations section 1.167(a)-5, the apportionment of purchase price between depreciable and nondepreciable assets is to be made proportionate to "value," 43 which the courts and Service have interpreted to mean "fair market value." 44 Section 1.1001 (a) provides that "fair market value" is a question of fact. ${ }^{45}$ The courts have treated it as such, occasionally using as a general standard the price a willing buyer would pay a willing seller. ${ }^{46}$

37 Id.

38470 F.2d 1107 (8th Cir.), cert. denied, 93 S. Ct. 2773 (1973).

${ }^{39}$ Id. at 1109 .

${ }^{40}$ Treas. Reg. \& 1.167(a)-3 (1956).

${ }^{41} I d$. $\S 1.167(\mathrm{a})-5$.

42 Id. $\$ 1.167(\mathrm{a})-3$.

${ }^{43}$ Id. $\S 1.167(\mathrm{a})-5$.

${ }^{44}$ See, e.g., Philadelphia Steel \& Iron Corp., $23 \mathrm{CCH}$ Tax Ct. Mem. 558 (1964), affd per curiam, 344 F.2d 964 (3d Cir. 1965); Ruhe, supra note 10, at 51. Cf. Texas-Empire Pipe Line Co. v. Commissioner, 127 F.2d 220, 226 (10th Cir. 1942); Cornish v. United States, 221 F. Supp. 658, 664, 665 (D. Ore. 1963), rev'd on other grounds, 348 F.2d 175 (9th Cir. 1965).

${ }_{45}$ Treas. Reg. \& 1.1001-1(a) (1957).

46 Commissioner v. Marshman, 279 F.2d 27, 32 (6th Cir.), cert denied, 364 U.S. 918 (1960); Helvering v. Walbridge, 70 F.2d 683 (2d Cir.), cert. denied, 293 U.S. 594 (1934). 
Some courts have relied heavily on the open market prices of similar assets, ${ }^{47}$ with recent sales of the same assets likely to be deemed conclusive 48 in ascertaining "replacement cost fair market value." 49 Others, however, have looked to all available evidence, ${ }^{50}$ including expert appraisals, ${ }^{51}$ taking into account not only market prices of assets but also studies of the past and prospective earnings of the business. ${ }^{52}$ One unhappy result of the use of different valuation methods has been the strong likelihood that somewhat differing tax consequences may be imposed on taxpayers similarly situated in all material respects. Although, as has been seen, depreciation of going concern value has been denied when sought directly, commonly-accepted valuation techniques give that result the IRS imprimatur, so long as achieved by indirection.

If a court relies exclusively upon strict replacement cost in determining fair market value, going concern value will not ordinarily be included in the value of physical assets, but instead will be either listed as a separate asset or assigned to goodwill as a catchall residual intangible. ${ }^{53}$ In either case depreciation will be denied. If, however, those same assets are assessed by a more sophisticated valuation technique that takes earnings into account, development costs and other components of going concern value will be subsumed in the market price. ${ }^{54}$ Once these

${ }^{47}$ See, e.g. Northern Natural Gas Co. v. United States, 470 F.2d 1107, 1110 (8th Cir.), cert. denied, $93 \mathrm{~S}$. Ct. 2773 (1973); Heath, supra note 18, at 55. 1929).

${ }^{48}$ See, e.g., Jefferson Planting \& Mfg. Co. v. Commissioner, 31 F.2d 753 (5th Cir.

${ }^{49}$ The price of new assets, plus installation costs, less estimated depreciation-or the price of used assets, if a used market exists - yields the "replacement cost fair market value." See note 54 infra.

${ }^{50}$ See, e.g., Morrisdale Coal Co. v. Commissioner, 97 F.2d 272 (3d Cir. 1938); Frazell v. United States, 269 F. Supp. 885 (W.D. La. 1967); Railway \& Express Co. v. United States, 56 F.2d 687 (Ct. Cl. 1932); Ingram-Richardson, Inc., 31 CCH Tax Ct. Mem. 779 (1972).

si See, e.g., Strong, Hewat \& Co., 3 B.T.A. 1035, 1037 (1926).

52 See Heath, supra note 18 , at 56 .

${ }^{53}$ See, e.g., George J. Staab, 20 T.C. 834, 840 (1953).

54 Even the relatively simplistic replacement cost method will permit various purchasing, shipping and installation costs to be included within an asset valuation undertaken by an informed purchaser. See P. GRAdy, Inventory Of GENERALly AcCEPTED AcCounting Principles For Business ENTERPRises 254, 255 (Accounting Research Series No. 7 1965); text accompanying note 75 infra.

Development costs of a trial-and-error nature, which fall within the definition of going concern value set forth in this Comment, would not, however, be included within a replacement cost asset valuation, but could readily be included in asset values by a more sophisticated valuation technique.

It may be that sophisticated valuation methods will not inevitably result in perfect subterfuge and depreciation of the entire going concern value. It must be conceded that in Northern Natural Gas, for example, the Commissioner objected to the taxpayer's valuation because no part of the contract price had been allocated to the "going concern value inherent in [the] . . . acquisition." Similarly, in Cornish the court contemplated that some value ought in the ordinary valuation be attributed to going concern value:

[T] he negotiated purchase price of the partnership breaks down into three classes; the fair market value of the tangible assets ... the part of the negotiated price which should be attributed to going concern value as a nondepreciable 
elements of going concern value are included within the value of depreciables, of course, the portion of going concern value they represent will be amortized over the assets' useful lives.

Thus, the more successful a purchaser is in valuing his newly-acquired assets with economic sophistication, the more favorable his tax treatment will be. Even if the taxpayer uses a replacement cost valuation of his assets, however, his going concern value may be at least partially depreciable, either as a result of latent Hexibility within the normally simplistic replacement method, ${ }^{55}$ or by virtue of an infrequently-authorized goodwill formula which makes possible the concealment of going concern value. As previously noted, the IRS frequently treats goodwill simply as the remainder of the selling price of a business after specified asset values have been subtracted; ${ }^{56}$ on other occasions, it prefers a separate, "all-the-facts" 57 valuation of goodwill and an apportionment of the price among all assets according to their respective values. ${ }^{58}$ It has, however, also authorized a formula approach for valuing goodwill when these other methods fail. ${ }^{59}$ That formula approach is as follows:

A percentage return on the average annual value of the tangible assets used in a business is determined, using a period of years ... immediately prior to the valuation date. The amount of the percentage return on tangible assets, thus determined, is deducted from the average earnings of the business for such period and the remainder, if any, is considered to be the amount of the average annual earnings from the intangible assets of the business for the period. This amount (considered as the average annual earnings from intangibles), capitalized at a percentage of, say, 15 to 20 percent, is the value of the intangible assets of the business determined under the "formula" approach. ${ }^{60}$

An industry's normal percentage rate of return, the above ruling goes on to provide, is what is meant by the "percentage return on the average annual value of the tangible assets used in a

intangible asset and the balance, representing partnership overvaluation, which should be prorated between the tangibles and the nondepreciable intangibles.

348 F.2d at 185-86 (emphasis added). Nonetheless, it is not clear that a court will closely scrutinize asset valuations which, unlike the Northern Natural Gas valuation, do not value purchased assets at a level dangerously close to their cost if new. And the Cormish formulation, while intimating that courts may well require some separate listing of going concern value, includes explicit sanction of an "overvaluation" factor which may be converted with some ease into a fudge factor.

${ }^{55} \mathrm{See}$ note 54 supra.

${ }^{56}$ See text accompanying note 14 supra.

57 Rev. Rul. 59-60, 1959-1 CUM. BuLl. 237.

58 See Ruhe, supra note 10, at 50, 51. Cf. Treas. Reg. § 1.167(a)-5 (1956).

${ }^{59}$ Rev. Rul. 68-609, 1968-2 Cum. Bull. 327.

${ }^{60}$ Id. 327. 
business." 61 Since the formula allocates to goodwill only that portion of value which exceeds the industry norm, the net result of using the formula approach will be a goodwill value which almost entirely excludes going concern value. Accordingly, if goodwill is valued by this formula approach and tangible assets and specific intangibles are valued according to a strict reproduction cost method, it is possible that going concern value will be kept separate from goodwill and from other asset values. Provided, however, the goodwill value arrived at by the formula method is accepted as reasonable, going concern value need not necessarily be recognized as a separate intangible. Instead, the actual consideration paid by the purchaser for going concern value will likely be denominated excess purchase price and distributed pro rata among the tangible assets, ${ }^{62}$ in which case depreciability will be achieved. ${ }^{63}$

\section{An Argument for Allowing the Depreciation Deduction in Limited Circumstances}

\section{A. Developer-Purchaser Discrimination}

The purchaser of a going business who is required to classify going concern value as a separate nondepreciable intangible is disadvantaged, not only as against the purchaser who succeeds in avoiding a separate valuation, but also as against the entrepreneur who initially developed that going concern value. The developer of going concern value achieves an immediate writeoff of his expenditures or delayed recognition of income from his efforts, while the purchaser gets no writeoff and begins to realize the higher income due to going concern value immediately after purchase. ${ }^{64}$ That difference in treatment is not in itself a decisive argument for allowing depreciation of going concern value, for a purchaser of goodwill is identically discriminated against. While the developer of goodwill may expense advertising expenditures $^{65}$ which help create customer preference, a purchaser of that customer preference gets no such deduction. ${ }^{66}$

The discrimination between purchaser and developer is partially remedied by the ability of the purchaser to obtain current deductions and delayed income recognition as he re-

${ }^{61}$ Id. 328.

${ }^{62}$ See United States v. Cornish, 348 F.2d 175, 185-186 (9th Cir. 1965); Treas. Reg. $\S 1.167(\mathrm{a})-5$ (1956).

${ }^{63}$ See note 54 supra.

64 Although the developer and purchaser will realize income from the business at the same rate, the former achieves deferred recognition of income from his entrepreneurial efforts while the latter receives only a normal return on his capital investment.

${ }^{65}$ But of. INT. REv. CODE OF 1954, \& $263(\mathrm{~b})$.

${ }^{66}$ See Treas. Reg. \& 1.167(a)-3 (1956). 
plenishes his fading going concern value. The purchaser is required only to retain the purchased going concern value. For tax convenience, allowance of this limited buyer-seller discrimination does not seem palpably unreasonable, even if theoretically suspect, when the lifespan of the purchased going concern value is not reasonably estimable. ${ }^{67}$ When, however, the longevity of going concern value elements is readily estimable, even this relatively small inequality appears unduly arbitrary.

\section{B. Doctrinal Considerations}

When any excess of the prchase price of a going business can be attributed to an intangible with a demonstrably limited useful life, whether that amount should be included in going concern value, goodwill, or asset valuation, it ought to be subject to the allowance for depreciation, under Regulations section $1.167(a)-3 .^{68}$

One reason for the Commissioner's firm opposition to allowing depreciation for going concern value is the past confusion of terminology, resulting in legitimate fears that "going concern value" might be converted by taxpayers into a catchall for otherwise nondepreciable intangibles. This objection can be overcome with relative ease, by demanding that taxpayers rigorously document the going concern elements enumerated in this Comment.

A second ground for opposition to going concern value depreciation-that going concern value may in some cases inseparably overlap goodwill ${ }^{69}$-is only slightly more stubborn. It is argued that in at least some oligopolistic industries, the line between goodwill and going concern value is scarcely a bright one. For, in such industries, the "normal rate of return" ordinarily reflected in going concern value will in fact reflect a value due to "customer preference" (or customer captivity) more properly denominated goodwill. This objection to allowing depreciation of going concern value in oligopolistic industries might, however, be assuaged by demanding a calculation of normal rate of return not on industry statistics, but on a broader range of business statistics, perhaps from kindred, nonoligopolistic industries.

67 It is, in fact, the selling entrepreneur, rather than the purchaser, who is treated most improperly. The entrepreneur has taken ordinary deductions and has not been required to accrue ordinary income due to his efforts. If, on the sale of his developed enterprise, going concern value, like goodwill, is treated as a capital asset, he will realize capital gain on a value created by ordinary expenses and ordinary income-producing efforts.

68 Treas. Reg. § 1.167(a)-3 (1956).

69 There was evidence of just such concern in the recent Northern Natural Gas Co. case. 72-1 U.S. Tax Cas. 84,623 (D. Neb. 1972), aff'd, 470 F.2d 1107, cert. denied, 93 S. Ct. 2773 (1973). 
The most basic ground for the opposition of the courts and IRS, their belief that going concern value does not have a reasonably estimable useful life, recalls and derives from their opposition to depreciation of goodwill. ${ }^{70}$ Despite forceful arguments by commentators that goodwill does in fact have a limited life, ${ }^{71}$ there has been no judicial approval of depreciation of purchased goodwill, ${ }^{72}$ and a similar rationale has been used to deny depreciation on purchased going concern value.

Such opposition seems at least partially misguided. Even positing the theoretical soundness of the Commission's approach to depreciation of goodwill, it appears simply wrong to maintain that no going concern elements have reasonably estimable useful lives. The unsoundness of that position is illustrated by the fact that many constituents of going concern and goodwill value may be depreciated currently if called by another name and included within an earnings-based valuation of assets, ${ }^{73}$ or when linked to depreciable intangibles with admittedly determinable useful lives, such as particular contracts, model designs or patents. ${ }^{74}$

This is not intended to suggest that the courts and Service should abruptly reverse direction and recognize going concern value as a monolithic, fully depreciable intangible. Even if going concern value as an entity could be shown to have a limited life, it is doubtful that such a peculiar life could be forecast accurately. Going concern value is continuously replenished by efforts and expenditures in the course of business, and its entire value cannot be said to exhaust at any one time. Purchased going concern value, as an aggregate, could thus be said to last the life of a business. If, however, going concern value is separated into its elements, useful lives can in some instances be estimated for at least some of those components. For example, organizational expenses and efforts clearly allocable to particular depreciable assets (but producing neither an adjustment to basis nor an expense under present law) must be reincurred upon replace-

${ }^{70}$ Regulations $\S 1.167(a)-3$ indicates that, to be depreciable, intangible assets must have a demonstrable limited life estimable with reasonable accuracy, and specifically declares that goodwill is not such an asset.

${ }^{7}$ See Frank, Goodwill Is Not Immortal: $A$ Proposal To Deduct The Exhaustion Of Purchased Goodwill, $23 \mathrm{~J}$. TAXaTION 380 (1965); Rolnik, The Probable Life of Goodwill as a Basis For Depreciation, 9 TAXEs 248 (1931); Amortization of Intangibles, supra note 4, at 863-64.

72 Although specific legislation has permitted amortization of certain intangibles over a relatively short period, see INT. REV. CODE OF 1954, \$§ 174 (research and experimental expenditures), 248 (corporate organizational expenditures), no similar legislation has allowed amortization of intangibles purchased as part of a going concern, and the requirement of a reasonably estimable useful life would necessarily prevail.

${ }_{73}$ See note 54 supra \& accompanying text.

${ }^{74}$ See Heath, supra note 18, at 57-58; Rettig, Tax Recovery of the Cost of Intangible Assets: Careful Analysis and Planning Necessary, $18 \mathrm{~J}$. TAXATION 154 (1963).

Cf. Northern Natural Gas Co. v. O'Malley, 277 F.2d 128 (8th Cir. 1960) (cost of pipeline easement can be depreciated over life of pipeline), acq., Rev. Rul. 71-120, 1971-1 Cum. Bull. 79. 
ment of those assets; given the ready calculability of such asset lives, those costs ought to be openly depreciable. ${ }^{75}$

Other elements of going concern value, however, cannot be included within or tied to tangible assets with a determinable useful life. Depreciation should not be allowed as to these values unless the intangibles themselves have demonstrably limited lives. Such limited lives will be difficult to identify in most ordinary businesses. Going concern value attributable to the organizational expenditures of an enterprise should not generally be amortized under section 167; unless these expenditures can in specific instances be tied to or included within the value of a depreciable asset such as a patent or model design, they would not appear to have demonstrable and limited useful lives. ${ }^{76}$

Still another major constituent of going concern value, the cost of assembling and training personnel, presents at least two special problems. First, training may result in abnormally high productivity and therefore generate goodwill inseparable from going concern value. Second, the efforts and expenditures relating to personnel development are constantly replenished. For both reasons, it will be devilishly difficult to establish a going concern value with a reasonably estimable useful life. Even if personnel attrition rates could be estimated from company and industry statistics, and an average amount expended for recruitment and training per employee could be calculated, the general inseparability of going concern value and goodwill attributable to employee structure would appear in itself sufficient theoretical justification for disallowance of depreciation deductions. ${ }^{77}$

Similarly, creditor and customer structure do not appear depreciable within any stretch of existing theory. First, it is doubtful that any expenditures or efforts can be allocated to attaining a particular customer, creditor or employee. Even if this feat could be accomplished without improper inclusion of goodwill, ${ }^{78}$ creditor and customer structure do not appear to have reasonably estimable or limited useful lives. ${ }^{79}$ For even

${ }^{75}$ See Northern Natural Gas Co. v. United States, 470 F.2d 1107, 1109 (8th Cir.), cert. denied, 93 S. Ct. 2773 (1973); P. GradY, supra note 54, at 254.

${ }^{76}$ This does not apply, of course, to organizational expenditures amortizable under $\S 248$, or research and development expenditures deductible under $\$ 174$.

Expenditures qualifying under the former provision would be allowed amortization over a period of not less than 5 years; while expenditures eligible for the latter would be permitted either a current deduction or 5-year amortization.

${ }_{77}$ This Comment, needless to say, has assumed for purposes of argument that current tax treatment of goodwill is soundly bottomed in theory. For an argument to the contrary, see Frank, supra note 71.

${ }_{78}$ Customer and creditor preferences have in the past been frequently treated as another name for goodwill. See Commissioner v. Seaboard Finance Co., 367 F.2d 646 (9th Cir. 1966); United States Indus. Alcohol Co. v. Helvering, 137 F.2d 511 (2d Cir. 1943); Richard M. Boe, 35 T.C. 720 (1961), aff'd, 307 F.2d 339 (9th Cir. 1962).

${ }^{79} \mathrm{Cf}$. note 76 supra \& accompanying text. 
though attrition rates for such elements might conceivably be calculated, ${ }^{80}$ the existing structures to a large extent appear to constantly replenish themselves.

\section{Conclusion}

Going concern value, an enterprise value attributable to hidden development expenses and efforts, contributes to a normal rate of return on tangible corporate assets. When it is overtly recorded as a separate asset by a purchaser, courts and the IRS refuse to allow depreciation deductions with respect to it. Yet as a practical matter, sophisticated valuation techniques routinely result in quiet concealment of the same going concern value within the valuation of other, depreciable assets, with the result that the sought-after deduction has been obtained by indirection. The disturbing result of the current vagueness with regard to going concern value is thus that two identically-situated taxpayers may be treated differently.

Discrimination also exists between a purchaser of going concern value and its developer, with the latter made the recipient of unduly favorable capital gains treatment. Even positing the wisdom of the current treatment of goodwill, the purchaser of going concern value ought to be able to depreciate at least portions of that value. While it would be improper for the courts or the Service to characterize going concern value as unitary and depreciable in full, it should be recognized that some elements of going concern value seem to possess the reasonably estimable useful life which is a prerequisite for depreciability. Thus depreciation can and should be overtly allowed on such value.

If reasonable scrutiny is given to taxpayers' assertions regarding the existence of a going concern value and the useful life of its constituent elements, there should be no real danger that going concern value will be used as a device for obtaining depreciation on intangibles for which such treatment cannot be justified. Recognition of the meaning of going concern value and the discrete character of its constituent elements is imperative for sound application of section 167 to the purchase of business assets. Unless some judicial light soon begins to shine on going concern questions, depreciation will continue wrongly to hinge on the valuation methods adopted by taxpayers, and not upon sound and equitable tax theory. 